\title{
A BRIEF REVIEW ON NOVEL REPURPOSING CANDIDATES FOR THE TREATMENT OF MYOCARDIAL INFARCTION
}

\author{
Folitartha Roy ${ }^{1}$, Kesha Desai ${ }^{1}$, Parasuraman $\mathrm{P}^{2}$, Md Azamthulla ${ }^{1}$ \\ Department of Pharmacology, Faculty of Pharmacy, M.S Ramaiah University of Applied Sciences, Bangalore- \\ 560054, India \\ Department of Pharmaceutical chemistry, Faculty of Pharmacy, M.S Ramaiah University of Applied Sciences, \\ Bangalore-560054, India
}

\begin{abstract}
Drug Repurposing has shown potent therapeutic effects of existing drugs on cardiovascular diseases (CVD). The use of repositioned drugs for Myocardial Infarction (MI) depends on the binding affinity of the drug molecules to the disease targets. Discovery of new chemical entities for cardiovascular diseases is challenging due to the increased expenses and lower rate of success. Therefore, there has been rigorous research on repurposing of the drugs with an aim to reduce mortality rate and associated symptoms of the disease. The advantage of drug repositioning is that, its safety profile is previously known thereby the probable adverse effects can be avoided. This article includes the comparison of the effects of few repurposed drugs for the treatment of Myocardial Infarction.
\end{abstract}

Keywords - Heart, Cardiovascular diseases, Myocardial Infarction, Coronary Heart Disease

\section{INTRODUCTION}

Heart - an amazing organ. A muscular organ which is of the size of fist is situated just behind the breastbone. The heart beats at a rhythm of about 60 to 100 times per minute. The heart pumps blood through its channels of arteries and veins which comprises the Cardiovascular System

Cardiovascular diseases include a wide range of disorders which include Coronary Heart Disease (CAD), Congenital Heart Disease, Myocardial Infarction and Hypertension.

A wide range of cardiovascular disease remains a leading cause of death in the USA \& few of it relies on the genetics and lifestyles. Among all the cardiovascular diseases, Myocardial Infarction accounts to 9 million death per year which is the prominent cause for global mortality. ${ }^{[1]}$ In India, cardiovascular diseases have been a major cause of death in males $(20.3 \%)$ and females $(16.9 \%)$ where WHO estimated 2 million deaths annually.

\section{Myocardial Infarction}

Myocardial Infarction has been observed more commonly in the younger generation with a different etiology compared to the elderly people.
The prime etiology of Myocardial Infarction is the decreased Coronary blood flow which results in insufficient oxygen supply to the heart leading to Cardiac Ischemia. ${ }^{[2,3]}$ Atherosclerotic plaque causes the inflammation of macrophages and monocytes, thrombus formation and platelet aggregation which ruptures the blood vessels causing thrombosis thereby leading to less blood flow in the coronary artery. $^{[5]}$

Few of the risk factors ${ }^{[6]}$ for Myocardial Infarction include:
- Age
- Sex
- Smoking
- Hypertension
- Diabetes Mellitus
- Lack of Exercise
- Obesity

\section{DISCUSSION}

The myocardium relies on aerobic metabolism for the production of the energy (Adenosine Triphosphate). Myocardial Infarction is mostly because of prolonged conditions of hypoxia and ischemia. Depletion in oxygen supply leads to enhanced anaerobic dependent ATP synthesis thereby causing necrosis of cardiac myocytes. The atherosclerotic plaque releases pro-inflammatory mediators like interleukin-6, monocytes, reactive nitrogen species. This leads to ischemia and finally results in the Myocardial Infarction. ${ }^{[7]}$ There is also increase in the cardiac biomarkers like the Total Creatinine Phosphatase (CPK), CPK-isoenzymeMB (CPK-MB), Lactate dehydrogenase (LDH), Troponin, etc.

\section{Drug Repositioning}

Drug Repositioning is a recent method of identifying the existing drugs for a new therapeutic purpose. This has enabled the mankind to progress in the field of treatment of various diseases. ${ }^{[8,13]}$ This review highlights on the marketed drugs which can be repurposed for the treatment of Acute Myocardial Infarction. 
III. TABLE NO. 1: LIST OF REPURPOSED DRUGS

\begin{tabular}{|c|c|c|c|c|}
\hline $\begin{array}{r}\text { Sl } \\
\text { No. }\end{array}$ & Drug & $\begin{array}{c}\text { Mechanism } \\
\text { of Action }\end{array}$ & Primary Use & $\begin{array}{c}\text { Repositioned } \\
\text { Use }\end{array}$ \\
\hline 1. & Acetylsalicylic acid & $\begin{array}{c}\text { COX } \\
\text { Inhibitor, } \\
\text { Thrombaxane } \\
\text { A2 inhibitor }\end{array}$ & Fever and Pain & $\begin{array}{c}\text { Stroke, Angina } \\
\text { and } \\
\text { Myocardial } \\
\text { Infarction }\end{array}$ \\
\hline 2. & Carvedilol & Beta blocker & Hypertension & $\begin{array}{l}\text { Congestive } \\
\text { Heart Failure }\end{array}$ \\
\hline 3. & Bromocriptine & $\begin{array}{l}\text { Dopamine and } \\
\text { Serotonin } \\
\text { receptor } \\
\text { agonist }\end{array}$ & $\begin{array}{c}\text { Parkinson's } \\
\text { disease }\end{array}$ & $\begin{array}{l}\text { Type II } \\
\text { Diabetes } \\
\text { Mellitus }\end{array}$ \\
\hline 4. & Nitroglycerine & NO release & Angina & $\begin{array}{c}\text { Raynaud's } \\
\text { disease }\end{array}$ \\
\hline 5. & Exenatide & GLP-1 agonist & T2DM & $\begin{array}{c}\text { Cardiovascular } \\
\text { outcomes }\end{array}$ \\
\hline 6. & Nepafenac & COX inhibitor & $\begin{array}{c}\text { Eye } \\
\text { Inflammation }\end{array}$ & $\begin{array}{c}\text { Diabetes } \\
\text { retinopathy }\end{array}$ \\
\hline 7. & Vanoxerine & $\begin{array}{l}\text { Dopamine } \\
\text { reuptake } \\
\text { inhibitor }\end{array}$ & $\begin{array}{c}\text { Cocaine } \\
\text { addiction }\end{array}$ & $\begin{array}{c}\text { Atrial } \\
\text { fibrillation }\end{array}$ \\
\hline 8. & Tadalafil & $\begin{array}{l}\text { PDE5 } \\
\text { inhibitor }\end{array}$ & $\begin{array}{c}\text { Erectile } \\
\text { dysfunction }\end{array}$ & $\begin{array}{c}\text { Pulmonary } \\
\text { hypertension }\end{array}$ \\
\hline 9. & Allopurinol & $\begin{array}{l}\text { Xanthine } \\
\text { oxidase } \\
\text { inhibitor }\end{array}$ & Hyperuricemia & $\begin{array}{l}\text { Coronary } \\
\text { syndrome, } \\
\text { Angina and } \\
\text { Stroke }\end{array}$ \\
\hline 10. & Bucindolol & Beta blocker & $\begin{array}{l}\text { Rejected for } \\
\text { heart failure }\end{array}$ & $\begin{array}{c}\text { Diagnosis of } \\
\text { Heart Failure } \\
\text { Genotype } \\
\text { defined Heart } \\
\text { Failure }\end{array}$ \\
\hline 11. & Rivaroxaban & $\begin{array}{l}\text { Factor Xa } \\
\text { inhibitor }\end{array}$ & $\begin{array}{c}\text { Oral } \\
\text { Coagulant }\end{array}$ & $\begin{array}{c}\text { Acute } \\
\text { Coronary } \\
\text { Syndrome }\end{array}$ \\
\hline 12. & Methamphetamine & $\begin{array}{l}\text { Sympathomi } \\
\text { metic }\end{array}$ & $\begin{array}{c}\text { Attention } \\
\text { deficit } \\
\text { Hyperactivity } \\
\text { disorder and } \\
\text { obesity }\end{array}$ & Heart Stroke \\
\hline
\end{tabular}




\section{International Journal of Engineering Applied Sciences and Technology, 2021 \\ Vol. 5, Issue 10, ISSN No. 2455-2143, Pages 140-143 \\ Published Online February 2021 in IJEAST (http://www.ijeast.com)}

\section{$\underline{\text { Bucindolol }}$}

Bucindolol is a competitive and non-selective $\beta$-receptor antagonist which stabilizes the abnormal cardiac functions. Bucindolol has equal affinity towards $\beta-1$ and $\beta-2$ receptors but has 30 fold lower affinities towards $\alpha 1$ receptors. An exceptional case in in-vitro study of the human myocardium for $\beta$-receptors, shows agonist binding site for bucindolol which mediated Intrinsic Sympathomimetic Activity (ISA) leading to positive inotropic effect. When compared to Labetolol, bucindolol shows higher $\beta$ blocking activity but are equi-potent on the $\alpha$-receptors. ${ }^{[9]}$ Bucindolol is a more potent $\beta$-blocking agent as compared to Carvedilol whereas its potency decreases for $\alpha$ receptors. Hence it is understood that bucindolol has effective $\beta$ blocking activity and thereby is a potent repurposed drug to treat Myocardial Infarction.

\section{Rivaroxaban}

Rivaroxaban is a direct oral anticoagulant which inhibits the Xa clotting factor by blocking the thrombin formation. Rivaroxaban works on Myocardial Infarction by inhibiting the Thrombotic cascade. Rivaroxaban is used as a Anti-Xa Therapy to reduce cardiovascular events in addition to the Acute Coronary Syndrome-Thrombolysis in Myocardial Infarction. ${ }^{[10]}$ However, the Rivaroxaban increase the risk of major bleeding but show potent action against spontaneous Myocardial Infarction.

\begin{abstract}
Allopurinol
Allopurinol lowers the uric acid by inhibiting xanthine oxidase and is used for the treatment of Hyperuricemia. The inhibition of Xanthine Oxidase reduces the radical oxygen species generation and vascular oxidative stress and has effective action against myocardial infarction. On the contrary, the dosage dependent relationship of allopurinol increases the risk of Myocardial Infarction. ${ }^{[6]}$ Allopurinol has cardioprotective effect at a minimal dose but at higher dose it increases the risk of Myocardial Infarction
\end{abstract}

\section{Exenatide}

Exenatide, a Glucagon-like peptide 1 (GLP-1) analogue shows antihyperlipidemic action. Along with, it exhibits cardioprotective action by reducing the infarct size in ST elevated myocardial infarction. During ischemic condition, the free fatty acids increase the oxygen demand by reducing the ATP generation. Exenatide reverses this condition by increasing the myocardial glucose uptake. Exenatide also triggers the phosphatidylinositol 3 kinase, which causes the activation of endothelial nitric oxide synthase possessing cardioprotective action. It also activates the protein $\mathrm{C}$ kinase which is cardioprotective in nature. Exenatide also imparts anti-inflammatory action in the treatment of MI. ${ }^{[12]}$ Thereby Exenatide acts on the treatment of MI through several mechanisms and it can be used as an effective repurposed drug against MI.

\section{Tadalafil}

Tadalafil, a potent selective, reversible phosphodiesterase 5 (PDE5) inhibitor is used for the treatment of erectile dysfunction. Tadalafil reduces the blood pressure when pretreated with nitrates. Tadalafil has shown vasodilation in only $0.43 \%$ of the patients as reported by the previous studies. ${ }^{[13]}$ The frequency of Tadalafil administration has to be minimal to avoid the cardiovascular adverse events.

\section{CONCLUSIONS}

\section{Future and Challenges}

Drugs which have failed in Phase II and Phase III clinical trials may be repurposed once the targets of unintended diseases have been validated. Different approaches are made for drug repositioning, out of which many of it are still in the primary phase of development on discovering a potential candidate, the intellectual proprietary rights of the molecule has to be considered where the role of generic version of the drug plays an important role. ${ }^{[8]}$ Generic drugs are provided at a lesser cost to balance the market competition. The alterations in the dose and route of administration can thereby protect the proprietary rights of the repositioned drugs.

Enhancement in the productivity of Research and Development through the prospects of drug repositioning has increasing demand for pharmaceutical companies. Drug repositioning still keeps a hope to conquer the hurdles in drug discovery and development.

\section{REFERENCES:}

1. Prabharkaran D., Jeemon P., Roy A. (2016). Circulation - Cardiovascular Diseases in India, pp. 1605-1620.

https://doi.org/10.1161/CIRCULATIONAHA.114.00 $\underline{8729}$

2. Anderson J.L. and Morrow D.A. (2017). N Engl J Med - Acute Myocardial Infarction. pp. 2053-2064. DOI: sci-hub.se/10.1056/nejmra1606915

3. Costa D.G. (2018). Pathophysiology - The pathophysiology of myocardial infarction-induced heart failure. Pathophysiology, pp. 277-284. DOI: $10.1016 /$ j.pathophys.2018.04.003

4. Krishnan.N. (2012). Indian Heart J. - Coronary heart disease and risk factors in India-On the brink of an epidemic? $\mathrm{pp}$. 364-367. DOI: 10.1016/j.ihj.2012.07.001

5. Neki N S, Singh J, Jitesh G, Sharma B R, Bharadwaj R, Meena $\mathrm{N}$ et al. (2017). Int. J. Curr. Res. Med. Sci. - Clinical profile of acute myocardial infarction in young patients. pp. 1-7. DOI: http://dx.doi.org/10.22192/ijcrms.2017.03.07.001

6. Liao K, Lin C, Lai S. (2019). Tzu Chi Medical Journal - Allopurinol use associated with increased 
risk of acute myocardial infarction in older people in a case control study. pp. 276-279. DOI: $10.4103 / \mathrm{tcmj} . t \mathrm{cmj} 144 \quad 18$

7. Zwaan C, Daeman M, Hermens W. (2001). Neth Heart $J$ - Mechanisms of cell death in acute myocardial infarction: pathophysiology implications for treatment. pp. 30-44.

8. Banerjee S, Katare P. (2016). Current Topics in Medicinal Chemistry. Repositioning of Drugs in Cardiometabolic Disorders: Importance and Current Scenario. pp.1-12

9. Hershberger R, Wynn J, Sundberg L, Bristow M. (1990). J Cardiovasc Pharmacol. Mechanism of Action of Bucindolol in Human Ventricular Myocardium. pp. 959-967 DOI: 10.1097/00005344199006000-00014

10. Cavender M, Gibson C, Braunwald E, Wiviott S, et al. (2015). European Heart Journal: Acute Cardiovascular Care. - The effect of rivaroxaban on myocardial infarction in the ATLAS ACS 2 - TIMI 5I trial. pp. 468-474. DOI: 10.1177/2048872614554109.

11. Woo J, Kim W, Ha S, Kim J, et al. (2013). Arterioscler Thromb Vasc Biol. - Cardioprotective Effects of Exenatide in Patients with ST-SegmentElevation Myocardial Infarction Undergoing Primary Percutaneous Coronary Intervention. pp. 2252-2260. DOI: 10.1161/ATVBAHA.113.301586.

12. Kloner R, Mitchell M, Emmick J. T (2003) Am. J. Card. - Cardiovascular Effects of Tadalafil. pp. 37M46M. DOI: 10.1016/s0002-9149(03)00074-2

13. Yang G., Ma A., Qin Z S. (2019). Front Genets - An Integrated System Biology Approach Yields Drug Repositioning Candidates for the Treatment of Heart Failure. p. 1-13. DOI: https://doi.org/10.3389/fgene.2019.00916 